\title{
Globalization of Higher Education: Notes about Economy, Knowledge Production and Impacts on Civil Society
}

\author{
João Dos Reis Silva Júnior ${ }^{1}$, Everton Henrique Eleuterio Fargoni² \\ ${ }^{1}$ Department of Education (DEd), Federal University of São Carlos (UFSCar), São Carlos, Brazil \\ ${ }^{2}$ Education by the Graduate Program in Education (PPGE) of the Federal University of São Carlos (UFSCar), São Carlos, Brazil \\ Email: jr@ufscar.br, evertonfargoni@gmail.com
}

How to cite this paper: Dos Reis Silva Júnior, J. and Fargoni, E.H.E. (2019) Globalization of Higher Education: Notes about Economy, Knowledge Production and Impacts on Civil Society. Open Access Library Journal, 6: e5869.

https://doi.org/10.4236/oalib.1105869

Received: October 20, 2019

Accepted: November 12, 2019

Published: November 15, 2019

Copyright $\odot 2019$ by author(s) and Open Access Library Inc.

This work is licensed under the Creative Commons Attribution International License (CC BY 4.0).

http://creativecommons.org/licenses/by/4.0/

\begin{abstract}
This article is a part of a broad research conducted between 2016 and 2019 on research funding policies, knowledge production and the researcher's work in the context of the globalization of higher education. The research aimed to verify the new paradigms of the researcher's work in the face of the advanced scenario of commercialization of knowledge produced in the global academic scope. In this context, the complex object of study unfolded in several situational cases, one of them being the inducing power of research and scientific work by large world corporations while crucial issues for human development appear in the background. For such, this text will discourse through occasional reflections based on the facts obtained, on the international economic order and on the trends of the globalized work in research.
\end{abstract}

\section{Subject Areas}

Economics, Education, Politics, Psychology

\section{Keywords}

Higher Education, Knowledge Production, Work Globalization

\section{Introduction}

In the present article, we propose to analyze the context of scientific work through the new world paradigms of knowledge production that are under advanced commercial force and, consequently, leaving crucial questions of civil society in the background.

Advancing scientific knowledge, innovating and generating solutions seem to 
have been adopted to unveil the world in order to develop it for the human mutual good, but these are concepts that most appear in the texts of mission definitions, visions and values of the numerous corporations that are getting closer to academic research centers in search of new products. Companies use the knowledge produced by undergraduates, postgraduates, research professors and technical scientists as raw material knowledge [1] which according to [2] "in a free translation" is "knowledge as a raw material to be transformed into products, processes or services to increase economic productivity". In fact, the so-called raw material knowledge is from 4 years ago. This research has shown that in universities, especially now with the FUTURE-SE program, this kind of economic epistemologically based knowledge is the product of the priority of program areas. These priority areas of FUTURE-SE are those that produce the new science; Technoscience, so we assume that raw material knowledge is commodity knowledge.

In the complex planetary conjuncture in which the economy is one of the main engines of social, human and scientific development, several questions are being made in search of solutions to the abundant world problems that result from the structural crisis that capitalism has been going through since 2008-2009. The universities in this broad framework appear as spaces of possibilities and high creative capacity to unveil profitable outlets for society, but it is also in the academic context that many inequalities appear, that is, universities as well as scientific centers with great potential. Value production, innovation and societal contribution are also part of the profuse scenario of economic and social imbalance.

In this sense, through punctual analyses with exemplary and analogous cases taken from the world and Brazilian academic reality, this text presents a clipping from broad research carried out between 2016 and 2019 and uses as a basis of reflection the contemporary world economic order and its impacts in the production of knowledge around the world.

\section{Civil Society Financialization}

To understand the economic movement that orders contemporary social processes across the planet, it is also vital to understand how science is produced in a world-wide context in the face of declining societies, sometimes by the destruction of nature in its intensified production plan, sometimes by social inequality, both accentuated in the 21 st century through economic engineering that does not prioritize social welfare because of the complex dynamics of production that cater to far more market trends rather than human needs.

Science in this globalized economic motto seems to be shifting to a new form of knowledge production, a form that does not primarily interact with the basic needs of the world's largest population base, because it hurts the existence of humans to create new resources to meet, for example, tech trends, with measures that are closest in expanding from science to entertainment and high-tech while millions of people suffer in misery on the same globe. 
Dowbor in quoting Wolfgang Streeck [3] clarifies this world conjuncture by exposing nations' indebtedness to the "market", causing countries to turn their backs on citizens by reproducing a common fact in the 21 st century governments that do not respond to the interests of the population that is, the life of the average citizen is precarious by the interests of finance capital. This condition is widespread in global geopolitics with alarming numbers of economic inequality, as the report by the Oxford Non-Governmental Organization Oxford Committee for Famine (OXFAM $)^{1}$ shows, revealing that eight billion families are holders wealthier than the poorest half of the world's population by 2018 .

Analyzing this reality of wealth accumulation, human beings still figure as a strategic component for financial groups, but not as the target of equity as some entrepreneurs say, the human being in this voracious globalized practice lives under a hostile territory in which the human being lives. Profit is worth much more than life. For example, according to the report on the public good or private wealth? presented in January 2019 by OXFAM ${ }^{2}$, if all the unpaid work done by women around the world were done by one company only, annual revenues would be $\$ 10$ trillion, which is 43 times more than Apple, which in 2017 made a profit of $\$ 229.3$ billion. This information exposes the dimension of the disparity between the welfare of societies and the social policies that exist around the world.

According to Streeck,

In the economic mainstream there must be a conflict in a market economy between rival principles of allocation and can only be explained by a deplorable lack of economic education of citizens, or demagogy by irresponsible politicians. Economic upheavals such as inflation, public deficits, and excessive private or public debt result from insufficient knowledge of the economic laws governing the economy's functioning as a wealth-creating machine, or from a frivolous disregard for the laws in the selfishness of political power. This is quite different in the theories of political economy in that they take politics seriously. Such theories recognize market allocation as a political-economic regime among others, governed by the special interests of those with scarce productive resources that place them in a strong market position, while their alternative, political allocation, is preferred by those with little power. economic but potentially high political [4].

Streeck's analysis allows us to understand that it is not on the horizon of concerns of the world's major corporations to facilitate the entry of more popular representatives into the international political arena by two factors: 1 ) there is no

${ }^{1}$ Public Good or Private Wealth? Universal health, education and other public services reduce the gap between rich and poor, and between women and men. Fairer taxation of the wealthiest can help pay for them. OXFAM. Available at https://policy-practice.oxfam.org.uk/publications/an-economy-for-the-99-its-time-to-build-a-huma n-economy-that-benefits-everyone-620170.

${ }^{2}$ Public good or private wealth? OXFAM. Available at

https://oxfam.org.br/projetos/bem-publico-ou-riqueza-privada/. 
wide education network on economic theories, especially in countries considered underdeveloped, these are the main bases of cheap labor and 2) bitter capitalism cyclical crises like the Great Depression of 1929, so it is necessary for the representatives of the high world economic summit to seek new strategies to maintain such economic system. productive and profitable, even if it is through the destruction of rights and the precariousness of work.

In this system where the driving force of the economy is based on profit, many negative impacts impact on the numerous spheres that make up the development of humanity. Environmental and social issues are examples of points that are often overlooked by the market motivation that makes the most of natural resources, and in many cases production groups with slaved or acutely underpaid people are found working in unhealthy environments for over 12 hours a day in exchange for a poor financial raise, as is the case with Chinese workers ${ }^{3}$ who earn 4 cents for each doll that will be sold at Disney for the price of $\$ 45$.

The data in Graph 1 show the global conjuncture of inequality. At the top of the pyramid are the percentages of people holding more than one million dollars, with only $0.8 \%$ of the world's population with accumulated wealth of 142 trillion dollars, 19 times more than the $64 \%$ of the global population below $\$ 10,000$, the same range as people with near-zero incomes. These are terrifying numbers that show the modern day that although they have evolved in the creation and enforcement of human rights laws, they persevere inhuman signs of exploitation of man.

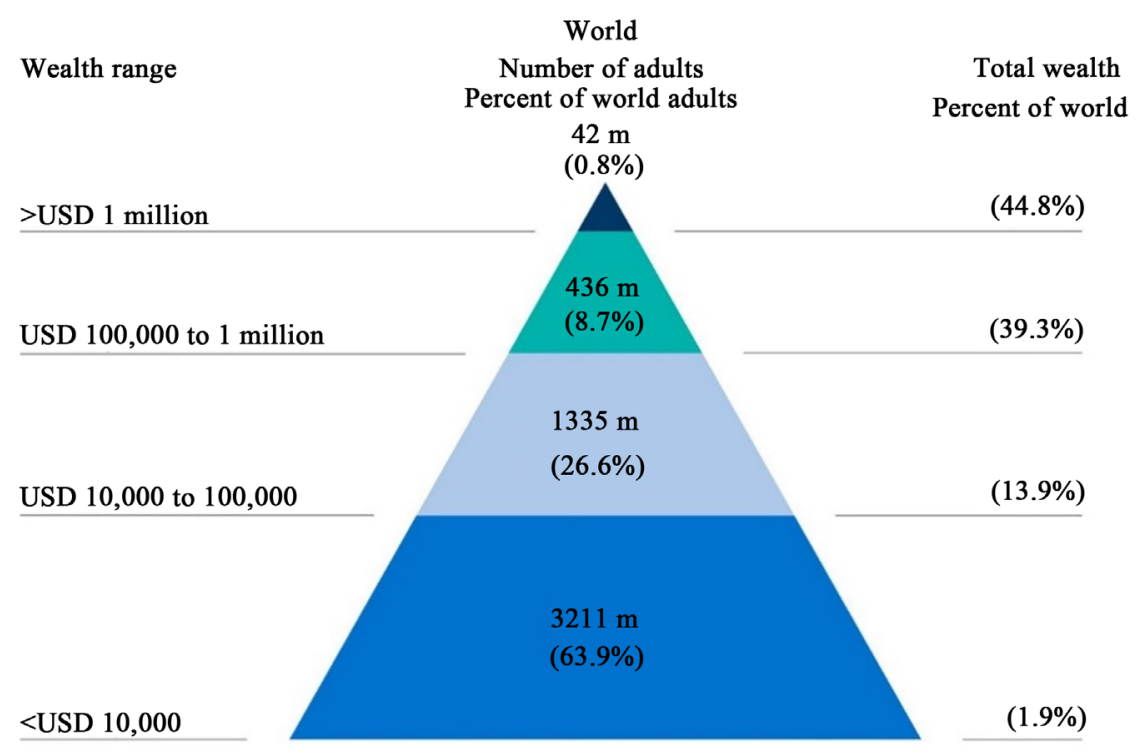

Graph 1. Pyramid of global wealth (2018) Source: Author's own elaboration based on Global Wealth Databook 2016-2018 indicators, Credit Suisse.

${ }^{3}$ Retrieved from

https://www.newsweek.com/chinese-women-workers-make-4-cents-producing-45-disney-dolls-1246 $\underline{857 .}$ 
In other data, the International Labor Organization (ILO) revealed that by December 2018 over 40 million people are still victims of slave labor ${ }^{4}$ in the world. This shows us that in the rationality of the facts under the financial hierarchical organizational logic, the holders of most of the income concentration became the regulators of the world market system and, therefore, influencers of the public policy order by which most the world's population experiences sporadic repairs, for example through Affirmative Actions.

\section{Knowledge or Work Society?}

With power hegemonically in the hands of the financial giants, not only does humanity preserve itself as a hostage to the decisions of the top of the pyramid, but science is also a prisoner of market deceit. To cite as an analogous case, the universities that engage most with private enterprise are bearing on the World Class University's foundational bases, while producing knowledge that is of substantial relevance to humanity, working much harder to attract new partnerships in the process. Of new funding funds, coincidentally coming from the large corporations worldwide that use the work of professor-researchers as a source of profit through the production of commodity knowledge.

[5] in discussing the problem of social imbalance in the world, raises the hypothesis that Higher Education is one of the best ways for the development of nations in many aspects, while he also exposes that obstacles exist in the academic conjuncture itself, that hamper the progress and redress of inequalities beyond the absence of public policies, that is, investment in higher education may be one of the most important transforming factors for emerging societies, but nation states instead of working with rank data Higher Education institutions acting on the numbers that point out the flaws or on the information with potential solutions to questions, end up highlighting the competition between the institutions, generating the dispute in the universities through the perspective of who produces more.

Such a contradiction is old and remains valid as explained by the Director of the Global Center for Higher Education (CGHE) Simon Marginson [6] in saying that mass higher education becomes necessary for a country to develop in many respects and to belong to a league. From developed countries, but at the same time there is the "importance" of making sure that universities are also part of a worldwide academic elite.

Another very important factor is how higher education works and will work in emerging countries while basic education follows the same linearity of social inequalities. In other words, one of the main concerns of nations that have the challenge of overcoming inequalities in their disparate historical particularities is human formation in Basic Education. This is also a challenge for countries con-

${ }^{4}$ More than 40 million people are still victims of slave labor in the world. United Nations (UN). Available at

https://nacoesunidas.org/mais-de-40-milhoes-de-pessoas-ainda-sao-vitimas-de-slave-abras-no-worl d/. 
sidered to be developed, because while in the world hierarchy few nations are advancing on educational issues, such as the success of Scandinavian social democratic countries, many other countries experiencing intense political problems are experiencing inadequate forms of financialization for educational development. of its population, weakening the General Intellect of the countries.

According to Graph 2, the poorest population, in terms of income, lives disproportionately in relation to public spending on education and this is repeated in other public services that according to OXFAM report,

In addition to these free services, social protection systems, such as family allowances and pensions, often represent additional cash income. They can also have a strong impact on reducing inequality. Evidence from Latin America shows that the introduction and expansion of social protection was one of the main factors driving the reduction of inequality in the region during the 2000s (OXFAM, 2019, p. 50).

The high concentration of income is not marginalized by the fact that most forms of enrichment are made possible by lawful means, but the figuration of income discrepancy in countries such as Papua New Guinea where the cost of water represents $50 \%$ of the daily income of a poor person, reveals that the world financial system does not ignore one of the basic conditions of survival of the citizen, because the public policies of each country follow the world order of human rights to ensure the human life.

However, corporate giants are always on the lookout not only at universities but with them to find sources of profit, even if they are to acquire a natural good on the planet. For example, through the intention of aquifer exploitation, wood from nature reserves, fossil fuels among others. Still, even with the decline in the world's poverty levels, what seems to prevail on the planet are the international financial connections, with trade as the driver of almost every field, because in the globalized market a country's political form of action depends on its economic structure and how this nation relates to other nations and, despite its singularities, the exploitation of natural resources in its territory, strengthening the national economy and, consequently, local science.

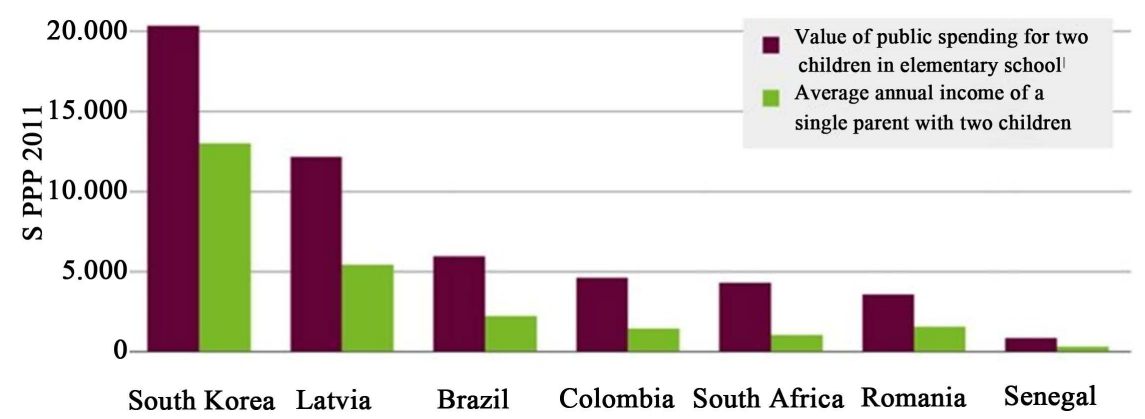

Graph 2. Public spending on elementary school compared to income of poorer families in different countries. Oxfam calculations. P. Espinoza Revollo, et al. (2019). In: Public Good or Private Wealth? Methodology Note. 
Alternative sources of funding come from large global corporations, of which their shareholders and owners are at the top of the global wealth pyramid, that is, they are directly and indirectly guiding research funding policies, inducing new academic practices in the production of knowledge and, consequently, of consumption on the planet. Such control can be visually measured by an OXFAM $^{5}$ marketing infographic for the Behind the Brands informative work, where fewer than two dozen brands and their industries, control thousands of other brands generating a not only market but financial monopoly as a principle. to maintain "investor confidence" [3] (Figure 1).

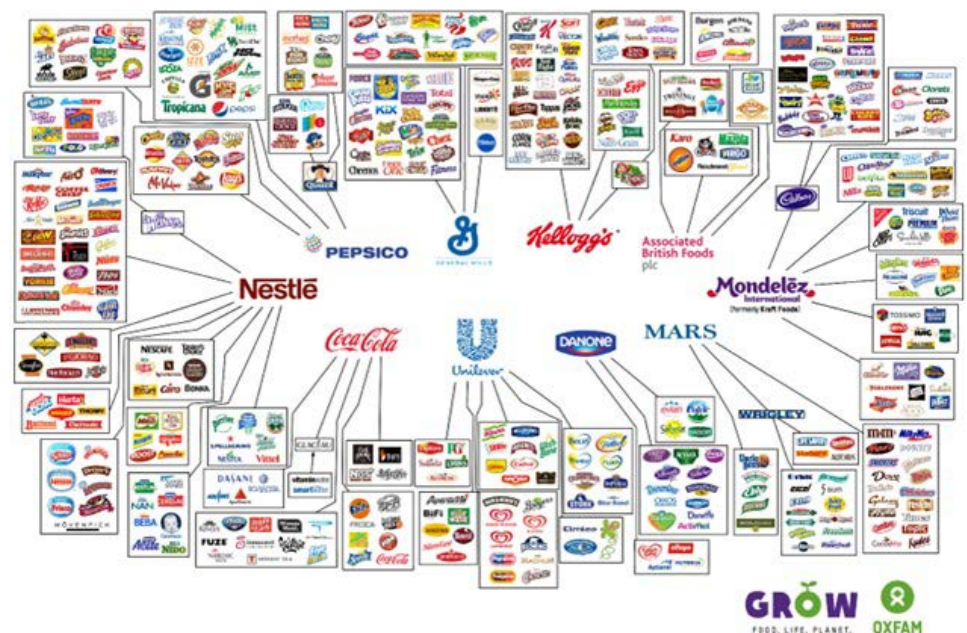

Figure 1. International industries and sub-brand control. Source: OXFAM Infographic, Take Action Behind the Brands, 2017.

According to the infographic, the prominent centralized companies form a monopoly of various markets such as: food, aesthetic products, hygiene and others. This makes these industries a method of cannibalizing local competition on most parts of the planet, weakening producers and smaller businesses and thereby affecting the region's economy. However, this marketing shakeout does not refer to the complete disappearance of competition through the merchants and producers of each country in dispute with the big corporations, but makes the big brands dominate most of the trade due to the large global advertising investment.

As an illustration, the Coca-Cola brand on the world knowledge production

${ }^{5}$ World Bank: Less than $10 \%$ of the population is below the poverty line. Brazil Agency. Available at http://agenciabrasil.ebc.com.br/internacional/noticia/2015-10/banco-mundial-702-milhoes-de-perso nas-vao-viver-na-poverty-extrema-em.

${ }^{6} \mathrm{Coca}-\mathrm{Cola}$ tried to innovate with tea products that addressed the problem of obesity. It introduced a brand of tea called Enviga, which was supposed to burn 60 to 100 calories for three 355-ml servings, but that claim was disregarded and sales of the product stalled. [...] these "rumors" spurred the media publicity campaign, but the scientific evidence came from a single unpaired study, sponsored by Coca-Cola and Nestlé, which a researcher at the University of Lausanne conducted alongside Nestlé headquarters in Switzerland. The study involved 32 healthy, normal, overweight individuals between 18 and 33 years of age whose energy expenditure was measured by the metabolic heat that came from their bodies after they drank by placebo [7]. 
circuit while investing ${ }^{6}$ in science and technology at the University of Lausane (Switzerland) in search of a new "calorie burn" product is also one of the industries that most pollute the oceans ${ }^{7}$. According to the Greenpeace Branded in Search of the World's Top Corporate Plastic Polluters report in partnership with Break Free from Plastic, multinational companies Coca-Cola, Pepsi and Nestlé are the biggest contributors to ocean pollution with waste plastic. In this ecological destruction ranking appear other multinationals such as Danone, Mondelez, Procter \& Gamble, Unilever and Mars Incorporated, same core industries of OXFAM's above-mentioned market monopoly infographic.

Given the complexity of the economy and the market-moving tangents, including universities, what seems to exist is the imbalance between the for-profit production method and the social organization of the countries in which resources are extracted or the hand of Cheap work. The environment lies in these two disharmonious poles; profit and social structure, but is more in the lucrative field due to reckless consumption by the world population and poor environmental education in most countries, especially underdeveloped ones that appear under economic conditions below large companies, such as Bolivia. Paraguay, Honduras and Costa Rica, countries that in 2016 had Gross Domestic Product (GDP) below the numbers of the US company Apple that ended the year with profit of almost 54 billion dollars.

\section{Higher Education in Face of Improductive Capital}

The redistributive power of tax collection and other forms of national financial collection rests with the state, and universities in the globalized context are increasingly distant from their governments' support for greater private financing. This organizational symbiosis between university and industry is one of the consequences of the induction of university institutions on the path of the World Class University, which on the one hand generate profitable patents due to the high injection of resources through private initiative and, such companies, are very attentive in the innovation market being financiers of the academic scientific centers mediating the works developed by the researchers in order to contain the mastery of new technologies and, preferably, the new scientific knowledge produced.

According to the political scientist and Director of the Harvard University Institute of Quantitative Social Sciences, Gary King, many academic researchers enter companies and become great consultants, enabling greater linkage between university research groups with industries and large corporations. This draws the productive and financial market into the university by placing it in the ${ }^{7}$ Branded in search of the world's top corporate plastic polluters. Greenpeace, 2018. Available at: https://www.breakfreefromplastic.org/wp-content/uploads/2018/10/BRANDED-Report-2018-FINAL pdf.

${ }^{8}$ Bayh-Dole Act or Patent and Trademark Amendment Act (Pub. L. 96-517, December 12, 1980) is part of US law dealing with intellectual property resulting from federally funded research. This Act arose from Congress "efforts to respond to the economic malaise of the 1970s. One of Congress" efforts was to improve the way we manage inventions created with over \$ 75 billion a year invested in Research \& Development. 
commercial economic realm by reproducing the Bayh-Dole Act ${ }^{8}$ in the globalized context.

For King (2019),

We can think of these academic consulting arrangements on a continuum: At one end, they can be highly restrictive, with tight control and pre-publication approval for example, for sensitive issues close to the company's core products. At the other extreme, they may have loose or pro-forma regulation usually when companies benefit from openness, allow collaborations between internal and external researchers, retain the right to patent prior to publication, and allow research on orthogonal topics for key products [8].

More broadly, this is a sample of the concern and approach of the private initiative with new solutions for the market using the university and the production of knowledge in the scientific researches in the world campuses. However, the question persists that if this is beneficial to the planet under the circumstances of a disparate socioeconomic architecture in which many potential scientists become obsolete, they may not even achieve notoriety.

Astrophysicist and scientific popularizer Neil deGrasse Tyson in an interview ${ }^{9}$ with the Spanish newspaper EL PAIS expresses that "the next Einstein may be starving in Ethiopia, and we will never know". Such speech exposes an important question about the economic inequality in the planet and the difficulty of knowledge production ${ }^{10}$ in underdeveloped countries. Neil's speech, though not written in a paper or book, is a very plausible statement in the context of global scientific and economic reality, because it clearly shows that the human condition was never the goal of political and economic organization in capitalism.

However, it has never become as acute as the worldwide practices of large corporations make evident. Basic and higher education, therefore, are organized according to the same rationality. Capitalism strikes once again at the structural crisis that leads to the dispossession of living labor.

At this juncture, the university, as well as a factory, becomes a provider of marketable products, making the knowledge generated by academic intellectuals become part of a complex system of production. According to [9] this operational university "is facing itself as a contract management and arbitration structure". In other words, "the university is turned inward, but (...) This does not mean a return to itself, but rather a loss of itself." And complements,

This university does not form and create thought, it strips the language of meaning, density and mystery, destroys the curiosity and admiration that

\footnotetext{
${ }^{9}$ Maybe the next Einstein is starving to death in Ethiopia. Nuño Domínguez. EL PAIS, 2016. Available at https://elpais.com/elpais/2016/06/30/ciencia/1467281442_280683.html.

${ }^{10}$ This is a topic that must be kept up for debate, because through affirmative actions and investments in basic education at all levels, from early childhood education to higher education, new scientists will be trained and will work not only for the production of marketable knowledge, but will research and seek solutions to various problems that directly affect civil society, whether in health or social.
} 
lead to the discovery of the new, nullifies all pretense of historical transformation as conscious action of human beings in certain material conditions [9].

It is in this context that it is necessary to understand the reality of today as the assumptions of tomorrow, since the scientist, regardless of whether he is the postgraduate student, professor-researcher or technical scientist of private enterprise all are under the logic of production in which they are not. have control and assist in the real interests of the "valorization" of the scientific product, that is, although the largest funding fund of Higher Education in the world context is still, in greater number, of state origin, the purpose of the knowledge produced in the present tends to yield more to innovation and profit rather than creating a scenario of emancipation and development that enables a "new Einstein" to emerge outside the richest countries on the planet.

Graph 3 shows that investments in R \& D through various sources of financing have grown since 1990, especially the federal source, which in 2011 surpassed $\$ 40$ billion even after the fiery global economic crisis of 2008 . The money invested in higher education has not been reduced by revealing how important public investment is in research and, therefore, in science production, because regardless of the economic situation education at any level, from basic to higher, is a great potential for societal transformation and development.

In another exemplary situation, in Brazil this could have proportional equivalence if the public fund remained without the brash cuts ${ }^{11}$ and less on the radar of large corporations as it intensified through the new Science, Technology and Innovation framework. This fact is quite noticeable in the reformed measures of article 4 on stimulating scientific development, research, scientific training, technology and innovation, forming the possibility of a public ICT.

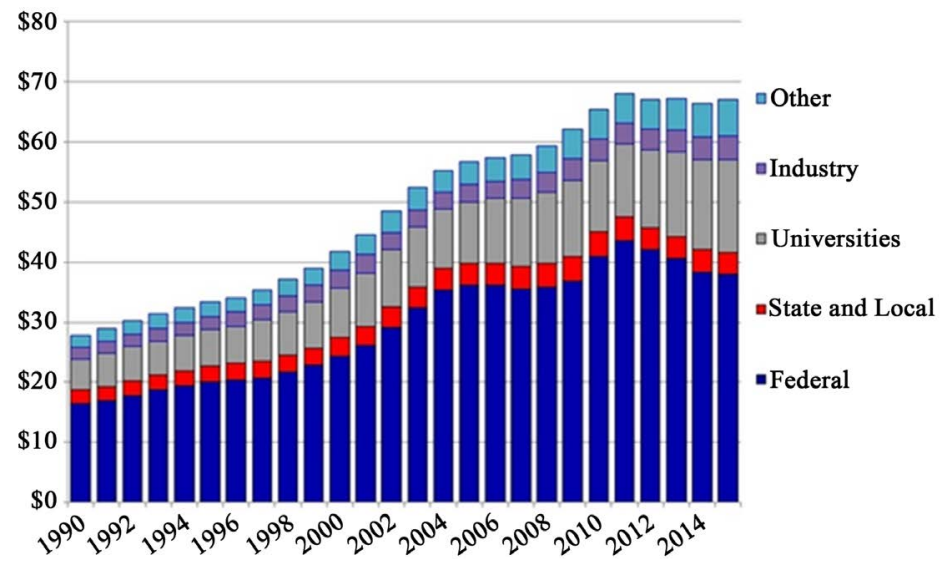

Graph 3. Research and development investments by value and source to us higher education institutions (In Billions of Dollars). Source: NSF, national center for science and engineering statistics, higher education R \& D series, 2017 AAS.

${ }^{11}$ Cutting the research budget puts the country's future at risk. Posted on Mar 282019 in the Journal of USP. Available at

https://jornal.usp.br/atualidades/corte-no-orcamento-de-pesquisas-coloca-futuro-do-pais-em-risco/. 
Passing from,

Sharing their laboratories, equipment, instruments, materials and other facilities with microenterprises and small businesses in activities focused on technological innovation, to achieve incubation activities, without prejudice to their final activity [10];

To,

Sharing their laboratories, equipment, instruments, materials and other facilities with ICT or companies in actions aimed at technological innovation to achieve incubation activities, without prejudice to their final activity [10];

This change reflects in a new system of research promotion, provoking a new professional paradigm, which further alters the way of work of the teacher who is also a researcher by placing it in the epicenter of the market ecosystem; educate and produce to generate profit. That is, companies, without exception, use public resources at some stage of their most successful projects. This does not seem bad from the point of view of some advances due to the level of investment, but it is necessary to mitigate the risks and it is probable that society understands this apportionment as economic knowledge.

\section{FUTURE-SE and the Americanization of the Brazilian University}

The narrowing of the Brazilian state university with private sector companies is not new in the contemporary economic conjuncture. After neoliberal ideas from the Washington Consensus (1989) unfolded in more than 60 countries, including Brazil, through the State Apparatus Reform in the 1990s, Brazilian public and private universities came even closer to the logic. Of the productive market in an intensified movement of "academic capitalism" [1]. This reform initiated the process of "Americanization" of the public university in Brazil and the FUTURE-SE Program attempts to consolidate this course two decades later.

In the 1980s, in the United States, the Bayh-Dole Act contributed to the expansion of patent production by US universities in partnership with companies. In Brazil, a very similar law sanctioned by Dilma Rousseff in 2016 called the "Milestone of Science, Technology and Innovation" boosted Brazilian universities on the same basis as US law. The text altered a series of actions on encouraging research and crucial points for scientific and technological development by regulating the relationship of academic research centers of state universities with private enterprise. In addition, by regulating long-term co-payments between the public and private sectors, it has increased the flexibility of action for Scientific, Technological and Innovation Institutions (ICTs) and their support organizations.

Three years later, a new approach program of Brazilian state universities with the private sector is presenting with forecasts that go beyond the objective condition of the proposed university-enterprise. The "FUTURE-SE" program not 
only aims to change the structural form of federal state universities, but also intends to reorganize the working conditions of teachers and other servants.

By associating universities and FIs to the future, without even outlining the dilemma of the Brazilian university issue, the absence of funding policies, the objective of the PL seems to be to adjust institutions to the new context of sharp decrease in public funding resulting from the EC 95./2016. In this sense, the PL is in accordance with the so-called Bridge to the Future, which called for an end to the constitutional linking of funds to education. In short, it is a transitional PL for a new model in which the State, unlike the Federal Constitution, relinquishes its duty to provide resources to municipalities and public foundations [11] (LEHER, 2019, p. 195).

In this context, Leher supports the progressive rationality of the Brazilian State Apparatus Reform that for 24 years and five presidents of different political fronts, all contributed in their ways in the reformulation of state universities towards the productive sector.

However, in 2019, FUTURE-SE intensifies neoliberal ideas in an unknown future because the program's structure is based on three axes that support the way of work, management and production of knowledge, for example, from the US university: 1) Management, governance and entrepreneurship; 2) Research and Innovation and 3) Internationalization.

These axes provoke different interpretations given the etymology of each item and the way the Program was presented by the Minister of Education Abraham Weintraub, since by rationalizing the economic direction of President Jair Bolsonaro and, above all, the Minister of Economy Paulo Roberto Nunes Guedes, the intention is to accelerate the reduction of state participation in the Public Sphere and, therefore, limit investment in Higher Education by forcing state institutes and universities to seek more resources beyond the public fund, which induces financial and social autonomy. Increasing or totaling the administrative participation of large corporations in university departments and research centers.

The proposals of the FUTURE-SE Program do not only change the university's management form, the propositions directly affect the production of knowledge by reorganizing the work of the teaching professors and, consequently, the formation of undergraduate and postgraduate students, as FUTURE-SE supports skills that, when operationalized, form employment contracts with research funded by the industrial sector that will intensify the use of the work of academic intellectuals to generate new technologies, consequently patents that will carry the university logo, but not their possible profits.

This model of scientific production already occurs abundantly in public universities and the study "Research in Brazil a report for CAPES", conducted by the US company Clarivate Analytics reveals that $99 \%$ of research in Brazil is done by public universities, with sovereignty Federal universities, 15 of them among the 20 that produce the most knowledge in the country. 
And what is the interest in accelerating and intensifying state universities, with a focus on federal ones, moving the institutions' autonomy and services to private enterprise? According to the Bill document that wants to institute the Entrepreneurial and Innovative Institutes and Universities Program (FUTURE), the basic idea is to make Brazilian public universities work with management contracts with Social Organizations (OS).

OS will not need to have direct approval from the Ministry of Education (MEC), as by presenting a solid financially based contract allowing for the "partnership" of scientific production and long-term resource management, reducing or neutralizing public investment, will need to make a public call. Contracts such as this induce the recruitment of professionals without the need for a public tender, which affects the career of Professors who are also Researchers by proposing that employees who work under exclusive dedication can perform paid research activities in the contracted OS.

The Program also constitutes fundraising through the commercialization of institution-branded goods and products, that is, by "turning" the public state university into a private state university, the OS-regulated institution markets artifacts with the university logo. As a commodity in which profit enters the accounting system in order to contribute to financial capital. Such congruence can be expanded in the form of sale of services by charging enrollments and tuition fees for latosensuand strictu sensu postgraduate courses ${ }^{12}$ and, consequently, also for undergraduate courses a topic that is widely addressed in the debate on educational policies for higher education.

This new condition and scenario of the Brazilian university by FUTURE-SE overestimates technoscience from the perspective of the productive market and suddenly reduces the public fund for investment in development, research, science and technology by emulating the "internationalized" formula of the US university, which is inspired by the ideas of the World Class University, but that after three decades of US patent law enforcement, serious consequences are needed to be discussed in civil society, because in addition to putting the research professors at the service of the productive market, changed the ethos of teaching work and did not contribute to the expansion of free higher education, maintaining restricted access to university for students from higher social classes inducing young people from other classes to seek alternatives to pay for universities.

As a serious consequence of the north American "FUTURE-SE" in 2019, students and college graduates in the United States are experiencing a disorder that is affecting the economy of the country sharply. According to data from the Federal Reserve, the US central bank, the US \$1.5 trillion undergraduate and graduate funding debt is $\$ 1.5$ trillion higher than the total US credit card debt in

${ }^{12}$ The Coordination for the Improvement of Higher Education Personnel (CAPES) published on December 20, 2019 a decree regulating the strictosensu postgraduate programs in the distance modality. All courses must follow the standards that apply to other postgraduate programs at the master and doctorate level. CAPES Foundation. Available at https://www.capes.gov.br/36-noticias/9279-regulamentacao-de-pos-graduacao-stricto-sensu-a-dista ncia. 
June 2019. This reality that has formed and is forming a generation of indebted youth has become the American election race agenda of 2020, and yet universities remain the condition of university-companies charging high values to citizens with a focus on the production of commodity knowledge.

This university format is what FUTURE-SE intends to emulate in Brazil. A format that ignores the country's social inequalities, highlights the technoscience for "profit" and scorns the humanities by proposing the financial autonomy of state universities leaving them vulnerable in the search for resources in large corporations. These are aimed at producing marketable knowledge, which reinforces the move from the humanities to higher education at a distance.

It is in this context, of precariousness of the public state university, that the FUTURE-SE Program presents itself and does not seem to solve the problem of the production of science and the expansion of free higher education in Brazil, on the contrary, it aims to transform the Brazilian public state university. at the American University, a model that is in crisis in the reference country.

The Brazilian case illustrates much of what is happening in the reorganization of the structure of Higher Education in the world. And all the bureaucratic weight of this institution and research funding system leverages another phenomenon, unproductive capital, which through minimal state control allows large corporations to dominate academic centers by generating innovations with few direct solutions to local and universal ${ }^{13}$ inequalities. In other words, "educational inequalities are a serious problem in Brazilian society and are related to the socioeconomic structure of the country" [12].

\section{Final Considerations}

The relational dimension is permanent and perpetrators' actions in terms of violation of basic social rights and practical exploitation of workers have a ripple effect. It starts at the top of the social pyramid and reproduces in the intermediate groups until it reaches the base segments [13].

In the academic field, scientific work and, consequently, the production and circulation of knowledge appear in two new contemporary faces: 1) the tendency to reduce public investment in research, especially in the humanities area, and 2) to increase strategic investment in research areas with great potential for innovation for the consumer (financial) market. For example, in the Brazilian case, such form is discussed as a parameter for granting postgraduate scholarships ${ }^{14}$.

\footnotetext{
${ }^{13}$ To get an idea of the complexity of this phenomenon, in the United Nations Food and Agriculture Organization (FAO) report 1.3 billion tons of food is wasted annually, causing major economic losses and a major impact on the planet's natural resources, whereas in the UN / FAO report on The State of Food Security and Nutrition in the World 2018 shows that for the third consecutive year there was an increase in the number of starving people in the world, an increase of 815 million people, in 2016 to almost 821 million in 2017. Food wastage footprint: Impacts on natural resources. FAO 2013. Available at http://www.fao.org/docrep/018/i3347e/i3347e.pdf.

${ }^{14} \mathrm{MEC}$ will use human development Index, course grade and priority area to award post scholarships. System designed by Weintraub management should focus on Health and Engineering programs, not Humanities. Retrieved from https://educacao.estadao.com.br/noticias/geral,mec-usara-idh-nota-de-curso-e-area-prioritaria-para -conceder-bolsas-de-pos,70002971476.
} 
Overcoming ideological simplifications in the imperative in which nations and their national policies can no longer regulate the globalizing economy, the nation-state, regardless of its financial position in the global market finds itself handed over to corporate policy properties and state apparatuses which were once governed by public policy in the face of their leaders' decisions, have become hostages to the commercial movement that exploits natural resources and manufacturing to the full. As a result, nations become servants of world corporations, and the production of knowledge in universities at the planetary level is faster under the logic of unproductive capital.

Therefore, the debate on various topics discussed in this article is of relevance to be broadened and much discussed, as research at various universities around the world and studies through global research centers constantly warn that what should be addressed with priority does not "generate profit" quickly and only show the multifaced of financial domination as a way of mastering human life. That is, the impression one has is that everything is for sale, even with the contrast of social dissimilarities explained by various intelligence agencies that constantly publicize flaws in public, educational and social policies in the various emergency margins.

\section{Conflicts of Interest}

The authors declare no conflicts of interest regarding the publication of this paper.

\section{References}

[1] Slaughter, S. and Rhoades, G. (2009) Academic Capitalism and the New Economy: Market, State and Higher Education. Johns Hopkins University Press, Baltimore, MD.

[2] Silva Júnior, J.R. (2017) The New Brazilian University: A busca por resultados comercializáveis: Para quem? Canal, Bauru, 6.

[3] Dowbor, L. (2017) A era do capital improdutivo: Por que oito famílias têm mais riqueza do que a metade da população no mundo? São Paulo, AutonomiaLiterária.

[4] Streeck, W. (2011) The Crisis in Context Democratic Capitalism and Its Contradictions. Max Planck Institute for the Study of Societies, Cologne. https://doi.org/10.2139/ssrn.1950558

[5] Hazelkorn, E. (2012) "World Class Excellence": Rankings and Emerging Societies. In Higher Education in the Global Age: Universities, Interconnections and Emerging Societies. Studies in Emerging Societies Series, Routledge.

[6] Marginson, S. (2012) Emerging Countries Need World-Class Universities. World University News.

[7] Marcus, A.A. (2015) Innovation in Sustainability: Fuel and Food. Cambridge University Press, Cambridge. https://doi.org/10.1017/CBO9781139680820

[8] King, G. and Persily, N. (2019) A New Model for Industry-Academic Partnerships. Cambridge University Press, Cambridge. https://doi.org/10.1017/S1049096519001021

[9] Chaui, M. (1999) A universidade em ruínas. In: Trindade, H., Org., Universidade 
em ruínas na república dos professores. Petrópolis: Vozes; Porto Alegre: CIPEDES, 211-222.

[10] Brasil, Lei No 13.243. (2016) Dispõe sobre estímulos ao desenvolvimento científico, à pesquisa, à capacitação científica e tecnológica e à inovação. http://www.planalto.gov.br/ccivil 03/ Ato2015-2018/2016/Lei/L13243.htm

[11] Leher, R. (2019) Análise preliminar do "FUTURE-SE” indica a refuncionalização das Universidades e Institutos Federais. In: Dôssie sobre o Programa FUTURE-SE do Governo/MEC e as implicações para a universidade e a sociedade, Grupo de Pesquisa Trabalho, Precarização e Resistências Centro de Estudos e Pesquisas em Humanidades/CRH-UFBa, 187-197.

[12] Garcia, A.V. and Hillesheim, J. (2017) Pobreza e desigualdades educacionais: uma análise com base nos Planos Nacionais de Educação e nos Planos Plurianuais Federais. Educar em Revista, No. 2, 131-147.

https://doi.org/10.1590/0104-4060.51386

[13] Cattani, A.D. (2007) Desigualdades Socioeconômicas: Conceitos e problemas de pesquisa. Dossiê Sociologias, No. 18, 74-99.

https://doi.org/10.1590/S1517-45222007000200005 